\title{
Perceptions of ESL Program Management in Canadian Higher Education: A Qualitative Case Study
}

\author{
Sarah Elaine Eaton \\ University of Calgary \\ Calgary, Canada
}

\begin{abstract}
ESL programs at post-secondary institutions must often generate revenue in addition to teaching students English. Institutions often impose explicit expectations on these programs to generate profit, creating unique challenges for those who administer them. This qualitative case study investigated challenges faced by ESL program directors at one university in Canada. Semistructured interviews were used to collect data from program directors $(N=3)$ on topics relating to administration, marketing, the mandate to generate revenue, and the complexities of ESL program legitimacy and marginalization in higher education contexts. Five key themes emerged from the data: (a) the necessity for directors to be highly qualified and multilingual, as well as have international experience; (b) a general lack of training, support, and resources for program directors; (c) institutional barriers such as working with marketers and recruiters with little knowledge of ESL contexts; (d) program fragmentation and marginalization on campus; and (e) reluctance to share information and program protectionism. Findings point to the need for increased training and support for ESL program directors, along with the need for institutions to elevate the profile of these programs so they are not viewed as having less value than other academic programs on campus.
\end{abstract}

Keywords: TESOL; language program management; administration; profit; revenue

\section{Introduction}

Directors of English as a Second Language (ESL) programs in higher education face different professional challenges than those of their administrative colleagues from other disciplines. ESL programs differ from other disciplines in fundamental ways (Rowe, 2012). First, students take ESL either as a form of skills training or to bridge into degree programs. They do not graduate with a major or minor specialization in ESL (Panferov, 2012; Staczek \& Carkin, 1984; Stoller \& Christison, 1994), and they often study English full-time and exclusively (Szasz, 2009/2010). In addition, ESL programs in post-secondary 
institutions exist, at least in part, to generate revenue (Eskey, 1997; Panferov, 2012; Pennington \& Hoejke, 2014; Staczek \& Carkin, 1984). As such, they often have separate tuition structures, admissions policies, and budgets (Pennington \& Hoekje, 2014), meaning that administrative approaches to ESL programs differ from others on a post-secondary campus. This creates a situation in which ESL programs are obliged to generate revenue for the very institutions in which they struggle to be regarded as legitimate contributors to the academic community. This qualitative case study investigates the experiences of three ESL program directors working in a Canadian higher education context, using semistructured interviews to gather data. Findings point to the need for further training for program directors, as well as increased institutional support, to ensure ESL programs are viewed as legitimate contributors to the campus community.

\section{Literature Review}

The challenges faced by ESL administrators are linked to the unique nature of their roles. The literature points to specific traits and training that an ESL program director is likely to have. In addition to the characteristics ESL program directors possess as individuals, two additional key topics emerged about the nature of ESL programs in higher education: the aspect of having to generate revenue while simultaneously being marginalized on campus. Each of these key topics inform a collective understanding of how ESL programs in higher education exist and are managed.

\section{Characteristics of an ESL Program Manager}

A typical ESL program manager has professional expertise in language learning and global education, and likely has international work experience (Rawley, 1997). Three separate survey studies, each surveying over 100 participants, found that over $90 \%$ of ESL program administrators held advanced degrees (Matthies, 1984; Panferov, 2012; Reasor, 1986). Reasor (1986) also found that ESL program managers are more likely to be "cautious, careful, conservative and orderly" (p. 341). A typical ESL program director has a combination of international experience, advanced degrees, and a conscientious and intentional approach to professional practice.

ESL directors are less likely to be tenured, less likely to hold a tenure-track professorship, and less likely to have time available for teaching or research when compared to academic administrators of other departments (Pennington \& Xiao, 1990). ESL directors may also have high levels of compassion, with a deep desire to help others (Rowe-Henry, 1997; Soppelsa, 1997). Despite professional expertise, academic qualifications, and altruistic intentions, the typical ESL director is likely to be regarded as less authoritative or influential than colleagues of similar academic rank in comparable roles.

To compound the issue further, ESL program directors are often ill-prepared to take on management roles and lack training in administration and business (Murdock, 1997; Nolan, 2001; Panferov, 2012; Pennington \& Xiao, 1990; Reasor, 1986; Rowe, 2012). Hussein (1995) found that over three-quarters of Teaching English to Speakers of Other Languages (TESOL) program graduates had received no training in management during their degrees. The result is that ESL program administrators often start out their careers as language teachers, thus 
having a strong knowledge of language acquisition and language teaching methodologies, leaving them only common sense and good intentions to guide them when they take on management roles (Stoller \& Christison, 1994). Only through practice and experience do most ESL program directors develop managerial competence (Hussein, 1995); therefore, their career development is neither systematic, nor extensive. The result is that ESL program directors often learn how to do their jobs by trial and error, fueled by a combination of common sense, good will, and grit.

\section{ESL Programs as Revenue Generators}

The notion of ESL programs as money-makers has a history reaching back almost half a century, when "a great many new [ESL programs] were established in the 1970s" (Eskey, 1997, p. 25), leading to the "widespread perception, probably accurate at the time, that such programs were sure-fire money makers" (Eskey, 1997, p. 25). The 1970s proved to be a pivotal point in the history of ESL at the post-secondary level, marking the first time international students began to populate ESL programs (Staczek \& Carkin, 1984). Eskey (1997) noted, "In any given year, larger numbers come from certain parts of the world (the Middle East in the 1970s, the Far East in the 1990s), mainly as a consequence of economic and political factors" (p. 22).

By the 1990s, ESL enrollments were booming, and simultaneously institutions began withdrawing centralized support from these programs, making institutional support conditional on enrollment and revenue generation (Staczek, 1997). Starting in the 1990s, financial solvency became a precondition for the existence of ESL programs in higher education.

That precondition continues to be a reality well into the 21st century (Rowe, 2012). But solvency was merely the beginning. The commodification of English language programs has become the norm in higher education (Pennington \& Hoejke, 2014), as they continue to be perceived as a "cash cow" for universities (Bista, 2011, p. 10; Eskey, 1997, p. 25; Kaplan, 1997, p. 7) and there is little indication that the situation of ESL programs as institutional revenue generators is going to change any time soon.

\section{ESL Program Marginalization and Struggle for Legitimacy}

ESL program directors struggle for legitimacy as professionals in an academic context (Breshears, 2004; Jenks, 1997; Jenks \& Kennell, 2012; MacDonald, 2016; MacPherson et al., 2005; McGee, Haworth, \& MacIntyre, 2014). Not only do program directors struggle for recognition as individuals, ESL programs as a whole remain marginalized and under-resourced (Eaton, 2013; Dvorack, 1986; MacDonald, 2016; Norris, 2016; Rowe-Henry, 1997; Soppelsa, 1997). Although ESL programs can bring significant value to an institution in terms of income generated, they continue to be regarded as "second-class" (Pennington \& Hoekje, 2014, p. 167) or "questionable" (Stoller \& Christison, 1994, p. 17). Unlike other academic administrators on campus, the work of the ESL program director includes helping the program achieve legitimacy (Jenks, 1997; Jenks \& Kennell, 2012).

To summarize, the literature presents a picture of the ESL director who is a highly qualified language teacher, has likely earned an advanced degree, has 
international experience, and has demonstrated diligence, intentionality, and conscientiousness. These individuals often lack management training but are given the task, by their institutions, of leading ESL programs that have evolved to be de facto cash cows. Concurrent to the responsibility of continually generating revenue, ESL program directors must also advocate to have their programs recognized as legitimate contributors to the academic communities they serve. Thus, it would not be an exaggeration to declare that the role of the ESL program director is both complex and formidable.

\section{Present Study}

The available literature on the administration of ESL programs has identified a number of concerns with program mandates, institutional support, and director capacity and skills. There is an identifiable gap in the research involving the collection of primary data in the area of ESL program administration, particularly in the last 25 years. Much of the literature is based on authors' personal experiences, scholarly observations of the field, and literature reviews. This study aimed to examine the issue from the perspective of ESL directors within a Canadian context. The following research question was investigated: (1) What do ESL program directors perceive to be the challenges and benefits of leading a revenue-generating program in a university? Two additional questions included: (2) What barriers do ESL program directors face in their roles?; and (2) What qualities or experience are necessary for an ESL program director to lead a revenue-generating ESL program in higher education?

\section{Theoretical framework}

There is a general lack of leadership literature within the TESOL field (Curtis, 2013; McGee et al., 2014). Greenier and Whitehead (2016) proposed a leadership model for English language teaching, which covered the notion of authentic leadership in the ESL classroom for teachers, but their work did not examine the role of administrators. Pennington and Hoekje (2010) presented a leadership model of language programs as an organizational ecology, noting the dependencies of various interconnected components and how they are affected by the larger context in which they exist (p. 214). Prior to that, only two edited volumes touched upon the topic of leadership in language program administration (Christison \& Murray, 2009; Coombe, McCloskey, Stephenson, \& Anderson, 2008).

The current study is framed within the context of Heifetz's notion of adaptive leadership (Heifetz, 1994, 2006, 2010; Heifetz, Grashow, \& Linsky, 2009; Heifetz \& Laurie, 1997; Heifetz \& Linsky, 2004). Adaptive leadership is relevant to the current study as it speaks to "work [that] is required when our deeply held beliefs are challenged, when the values that made us successful become less relevant, and when legitimate yet competing perspectives emerge" (Heifetz \& Laurie, 1997, p. 124). For ESL program administrators, the need to generate revenue as a necessary element of program management may deeply challenge their belief that the motives for education should be altruistic. The values, experiences, and expertise relating to second language teaching and language acquisition that made them successful as classroom teachers become significantly less relevant when they take on leadership roles. 
Heifetz et al. (2009) have contended that adaptive leadership needs to address current realities in which "urgency, high stakes, and uncertainty will continue as the norm" (p. 62). They specifically discussed the notion of leading adaptively in a situation of "permanent crisis" (Heifetz et al., 2009, p. 62). Although their study applies to leadership in a business context, it is equally relevant to ESL programs in higher education, because as Rowe (2012) pointed out, many ESL programs operate through "perpetual crisis management" (p. 109). The wording may differ slightly, but the notion of leading in conditions of unceasing crisis is a common denominator between them. What is compelling about this theory is that although it emerged from a business context, it applies equally well to ESL program managers, who are mandated to think and act as though they are running a business.

Crises in ESL can arise for a variety of reasons, including but not limited to those involving a single student, a program-wide issue, and factors internal and external to the program (Rowe, 2012). Hence, Heifetz et al.'s (2009) notion of leading in a permanent crisis was particularly relevant for the current study, as participants consistently indicated the need to adapt to a variety of uncertainties (e.g., institutional demands, market conditions, program enrollments) for their programs to survive.

\section{Research Method}

This study examines the professional reality of three ESL program directors whose experience parallels what the literature shows.

\section{Research Design}

Qualitative case study (Merriam, 1988; Merriam \& Tisdell, 2016) provided the overarching research design to address the research problem. Chapelle and Duff (2003) pointed out that a university or a program is among the kinds of cases typically studied in the TESOL field. The bounded case was a higher education institution in a large urban Canadian city, with a combined enrollment of over 30,000 full- and part-time degree students. The institution was of particular interest as it housed three distinct ESL programs operating on one campus, all of which were administratively independent of one another. Two programs were housed within the same faculty, but their directors reported to different senior administrators. The third was housed in an entirely different unit on campus. All three programs were mandated to generate revenue. None of the three program directors were required to interact with one another as part of their daily job functions.

It is worth adding that the number of students registered in these ESL programs was neither disclosed nor publicly available through institutional documents. As I have pointed out elsewhere (Eaton, 2009), ESL programs in higher education institutions are often not required to release enrolment data. Thus, the total enrollment of ESL students in the various programs studied remained unknown throughout the research.

\section{Participant selection}

Directors of each of these revenue-generating ESL programs on campus gave their written consent to participate, with the option of withdrawing at any time 
during the process $(N=3)$. Participants are referred to by their chosen pseudonyms (Lynn, Uma, and Ornelle). I used nonrandom purposive sampling (Blackstone, 2017; Merriam, 1998) to recruit participants because gaining access to individuals who were deeply informed about the various programs was key to collecting appropriate data (Saunders, 2012).

\section{Procedures}

This study, and related components including data collection instruments, participant recruitment plan, and consent form, were approved by the institutional ethics review board. Data were gathered through 60- to 90-minute semistructured interviews (Fylan, 2005; Harrell \& Bradley, 2009; Luo \& Wildemuth, 2009). I transcribed the audio recordings, and the participants then member checked the transcriptions for accuracy. Data were analyzed manually, following a systematic codifying and categorizing of the data into themes (Saldaña, 2009). In addition, I wrote analytic memos (Saldaña, 2009) to document my reflections about coding choices and emergent patterns resulting from the analysis.

\section{Findings and Discussion}

Five key themes emerged from the data codification process: (a) the need for directors to be highly qualified and multilingual, with international experience; (b) the general lack of training, support, and resources for program directors; (c) institutional barriers; (d) program fragmentation and marginalization; and (e) program protectionism. Each of these key findings is discussed in detail.

\section{Theme 1: Highly Qualified, Multilingual Professionals with International Experience}

All three participants agreed that having a minimum of a master's degree gave them credibility among their peers, both internal and external to the university. This finding aligned with previous studies that showed over $90 \%$ of ESL program directors in the United States held either a master's or a doctorate degree (Matthies, 1984; Panferov, 2012; Reasor, 1986). All participants spoke at least one additional language and had lived and worked in other countries. Table 1 offers a high-level overview of participants' qualifications and experience. 
Table 1: Profile of ESL Program Directors as Study Participants

\begin{tabular}{|c|c|c|c|}
\hline \multirow[b]{2}{*}{ Variable } & \multicolumn{3}{|l|}{ Participant } \\
\hline & Ornelle & Uma & Lynn \\
\hline Gender & Male & Female & Female \\
\hline $\begin{array}{l}\text { Length of time in } \\
\text { the profession }\end{array}$ & 16 years & $\begin{array}{l}9 \text { years } \\
\text { (including } \\
\text { graduate school) }\end{array}$ & 33 years \\
\hline Higher education & $\begin{array}{l}\text { MEd, TESL, some } \\
\text { business courses }\end{array}$ & $\mathrm{PhD}$ & $\begin{array}{l}\text { Master's degree, } \\
\text { TESOL }\end{array}$ \\
\hline $\begin{array}{l}\text { International } \\
\text { experience }\end{array}$ & Japan & U.S. & $\begin{array}{l}\text { UK, Spain, Italy, } \\
\text { Saudi Arabia, } \\
\text { China, Oman }\end{array}$ \\
\hline $\begin{array}{l}\text { Other languages } \\
\text { spoken }\end{array}$ & Fluent in Japanese & $\begin{array}{l}\text { Fluent in Bengali; } \\
\text { functional skills } \\
\text { in Hindi; } \\
\text { knowledge of } \\
\text { French and } \\
\text { Spanish }\end{array}$ & $\begin{array}{l}\text { Fluent in Spanish; } \\
\text { knowledge of } \\
\text { French and Italian }\end{array}$ \\
\hline Job classification & Administrative & $\begin{array}{l}\text { Academic } \\
\text { (tenure-track) }\end{array}$ & Administrative \\
\hline
\end{tabular}

\section{Theme 2: General Lack of Training, Support, and Resources}

Ornelle had taken business courses during his master's degree, noting that his decision to do so was purposeful:

The tools that I needed to serve my students, I felt, would be better served by improving operations, by improving my understanding of what it was that my students needed as customers, what was the best way of reaching the students, the best way of ensuring the deliverables. So those courses I took were ... very valuable.

Ornelle further reflected that his customized combination of graduate-level training in both TESL and business prepared him well for his role, but he noted that his experience was not the norm: "I think the combination of the two was very beneficial. . . . I haven't really heard of other ESL program directors or managers who ... have formal training in marketing or who have a specific interest in following a marketing directive." Ornelle's language reflected his 
training in business. During the one-hour interview, he referred to students as "customers" 26 times.

Lynn also referred to students as "customers," though she noted her training in business was "little to none". She remarked, "You're expected to do an awful lot without any professional knowledge, which is quite extraordinary, really, when you think about it. It does not happen in the business world." Lynn expressed frustration about institutional expectations for high performance as a manager, coupled with a lack of training and support:

I think there's a certain expectation that because of your knowledge or intelligence base, you will somehow pick it up like osmosis, you know? You are expected to know or learn how to do these things and in fact, you don't and can't without training. And if you don't, you are in a . . . situation whereby you're made to feel that ... [you shouldn't] talk about it. ... Go off and do it on your own.

Lynn later observed that being more educated about management would have not only increased her confidence, but also connected her with others who had an interest in same subject.

Both Lynn and Ornelle held jobs with administrative job classifications, rather than faculty positions, and hence their jobs were dependent on student enrollment. This finding aligned with the literature, which showed that staffing for ESL programs often depends on program enrolments (Mickelson, 1997; Staczek, 1997). Uma, on the other hand, held both a doctoral degree and a tenure-track faculty position. With regards to her training in business, she was emphatic about her lack of training: "Absolutely nothing. . . . Zero. Zilch. If it could be a negative integer, that's what it would be," noting that she was "trained to be an academic."

Both Lynn and Uma stated that they would have benefitted from business training. They observed that they had to learn necessary skills on the job, making mistakes as they went. Uma explained, "Because this is an academic program, you really need someone who understands all of the . . . key components to running this program [including] marketing, which is the one place I have a complete deficit in knowledge." As Uma continued to reflect on her experience, she noted that she had developed expertise through practice and experience: "[I have] grown. Maybe I'm not at zero any more. And I've learned quite a bit on the fly."

All participants agreed that training in business would be an asset for language program directors. These comments echo what was found in the work of Kaplan (1997), Nolan (2001), and Pennington and Xiao (1990), all of whom noted that ESL administrators are generally poorly prepared to undertake essential management functions. Moreover, unless they make a point to seek out courses independently, they have few professional development opportunities.

Lynn noted a cause-and-effect relationship between her lack of training and making mistakes: "There's not a lot of that kind of professional development support that I have seen or that has been offered. So of course, you make mistakes. You make some very big mistakes." Lynn seemed to be indicating that a lack of training led to negative consequences in terms how well she has performed her job. 


\section{Theme 3: Institutional Barriers}

The participants encountered other barriers as a result of working in a large organization. These included a requirement to work with internal marketing teams who did not understand the ESL market. Ornelle explained that "working in international education is far more complicated because ... you' re working at an international level." He went on to explain that his own international work experience contributed to his understanding of some of the complexities of marketing to global audiences.

Lynn spoke about the time she lost working with colleagues from other units on campus to develop brochures for her program. Similarly, Uma noted that printed marketing materials produced by the institution sometimes lacked an understanding of what might appeal to international audiences. She remarked:

I think people in the unit know what the needs of the unit are, and I think it's really not good when the marketing is done externally by another unit ... that has no understanding of how the language unit functions, what their demographics are. I think usually someone will come in and ask for stats and say, "How many students do you have? What languages do they speak?" And then they're off making marketing materials. But they don't ask the right questions, as to who's your audience, who's making the decisions? Parents? Is it the students? What socioeconomic background are your students? 'Cause that is huge.

In addition to barriers related to marketing, one additional challenge noted by both Uma and Lynn was that their programs had undergone extensive changes in the previous few years, and even as recently as a few months prior. This included changes to the program name, curriculum, structure, and staffing. Uma talked about "a total revision and restructuring, not only of faculty and staff, but in curriculum" and then, two years later, the program "went through another revision and a massive overhaul to curriculum." Uma noted that in her program's nine-year existence, it had undergone three name changes, finally settling on "English for Academic Purposes." Lynn had also faced the task of redesigning and reconceptualizing her programs, under the direction of her superiors. She, too, noted that her program had undergone three name changes over a five-year period, each time requiring a complete overhaul of the marketing materials to match the name changes. She was happy with the transformations her program had undergone, noting: "We're now a centre. We're in a position to create a brochure for the centre, which represents everything we do."

Both Lynn and Uma observed that these administrative and operational changes were, to a large extent, imposed on them by their institutional superiors. These monumental changes were largely beyond their control, even though they were the directors of their respective programs.

\section{Theme 4: Program Fragmentation and Marginalization}

Although Lynn and Uma both commented on the changes their programs had undergone in the previous few years, they also expressed a desire to differentiate their programs from other English language programs on campus. Lynn commented that the target market of her program in its early days "was immigrant professionals, as well as international professionals, all of whom are 
[learning] English as an additional language. And that ... distinguished us from ESL." She further noted, "We have been avoiding any undergraduate student work because that's very much covered by other programs in the university." Both Lynn and Uma noted that the changes to their programs (including the name changes) were partially intended to differentiate their programs from others on campus and to prevent confusion among prospective students.

Ornelle commented on how his program was marginalized even within the larger unit in which he worked. He commented that others perceived his program as follows:

ESL is special. ESL always wants something. ESL always has needs that seem to go . . . beyond what anybody else requires, and its expectations are too high or they're too low or this, that, or the other. . . English instruction is always seen as second class, or maybe fifth or sixth class.

This perception may be due to the fact that although the ESL program "exists within the culture of the university at large, [its] culture contrasts sharply with the institution of higher education, and as a university entity it is often misunderstood" (Rowe-Henry, 1997, p. 77). Perhaps because they differ from other academic courses, ESL programs are marginalized within the institution, isolated from other disciplines, and often viewed as being remedial (Carkin, 1997; Stoller, 1997).

Stoller (1997) suggested that the physical placement of a program on campus is indicative of the importance the administration places upon it. If it is relegated to some distant space that is not easily accessible, then it is likely that the program struggles to claim a legitimate place in the academy. Stoller (1997) observed, "That language programs are viewed as marginal-physically and educationally - by our home institutions represents a major hindrance" (p. 40). One cause of job dissatisfaction among ESL teachers is poor facilities (Jenks \& Kennell, 2012; Pennington, 1991).

In this study, all programs were situated in locations that were awkward to access or away from centralized administrative support. One program was housed in the basement of a building with no exterior windows. A second was located on the 14th floor of a building with convoluted access, as the elevator reached only the 13th floor. After that, people were required to exit the elevator and take stairs to the next floor up. The third program was housed in a small and cramped office, away from central administrative support. Jenks and Kennell (2012) suggested that advocating for enhanced facilities is one of the many job tasks of the ESL program administrator in higher education. They noted that if ESL learners in higher education are viewed as degree-seeking students, often "universities decide to improve or update . . . facilities and rethink poor policies regarding classroom space arrangements" (Jenks \& Kennell, 2012, p. 183).

\section{Theme 5: Program Competition and Protectionism}

It is noteworthy that none of the program directors interviewed indicated any desire to cooperate with other ESL programs on campus. Lynn observed that "everyone's working in silos and there's no ... team approach." Each program director undertook his or her own marketing and recruitment efforts, with no 
discernible collaboration. This lack of cooperation may have been a function of each program being housed within a larger administrative unit.

Although some distinctions existed as to what type of students were eligible for each program, there was also some overlap, creating a situation in which programs might compete for the same prospective students. There was little evidence to suggest that there was a strategic institutional approach to delineating and differentiating these programs. Program directors commented on how they tried not to duplicate one another's programs, but this was more of an ad hoc approach rather than a result of an institutional strategy.

For Lynn, revamping the program's website was the impetus for doing market research and, in particular, surveying what other ESL providers (who were also potential competitors) were doing. She said that the process of redesigning the website:

forced us to look out and see what everyone was doing, so that we didn't duplicate the services of the other programs on campus particularly, and we didn't duplicate what was being done really well elsewhere, outside of campus by other groups in the city.

Participants in this study offered comments that indicated a sense of protectionism over their own programs and a reluctance to share information deemed to be proprietary. The result was a notable lack of communication between the three program directors, with a veritable sense of competition among them. Impey and Underhill (1994) explained that "for all language programs, there is the constant threat that our competitors will get an edge over us, will find out how to exploit that lead successfully, and will take business away from us" (p. 8). In the case of this study, competition came not only from outside the institution, but also from within it.

\section{Directions for Future Research}

The reasons why a university would fail to develop a unified institutional strategy for ESL remain unanswered, which may be a topic for future investigation. In addition, this study points to the need for further investigation of how higher education ESL programs are managed, particularly in revenuegenerating contexts. There is a need to advocate for better support from institutional administration in terms of working conditions, resources, and support for program directors. Finally, there is a need to further understand the needs, perceptions, and experiences of TESOL administrators in order to develop better training programs for graduate students who may well serve in a leadership capacity at some point in their career, and also to develop better professional development opportunities for those currently in leadership roles.

\section{Conclusion}

This study has presented a unique and complex case of multiple revenuegenerating ESL programs existing within a single post-secondary institution. Its significance lies in the new insights it offers into the realities of ESL language program directors working in within the context of this bounded case study.

\section{Generative Modest Extrapolations}

Although case studies are often deemed to lack generalizability, Merriam and Tisdell (2016) have argued that the concept of generalizability applied to 
quantitative studies can be misplaced in qualitative research contexts, and instead researchers can point towards a "working hypothesis" or "modest extrapolation" (p. 255) generated as a theoretical outcome of a qualitative investigation. Given that the body of literature that exists on ESL program management corroborated the findings of this small-scale study, it would not be an overestimation to offer a generative working hypothesis that ESL programs in higher education require a specific kind of director or manager. Furthermore, the job the ESL program director differs from their counterparts in other academic disciplines.

ESL program directors must not only have subject matter expertise in TESOL, possess a graduate degree, speak at least one additional language, and have international work experience to carry credibility in the field, but in addition understand educational administration and possess the business acumen necessary to generate the robust revenue needed to sustain their programs. This is an exacting combination cultivated through the trajectory of a career, not merely a set of skills a junior TESOL professional would likely have. In other words, TESOL skills alone are insufficient to run an ESL program in higher education. Similarly, transplanting a manager from a different discipline or business background would be unsuccessful, given that a professional TESOL background is needed for the manager to be viewed as credible by colleagues and partners.

Panferov (2012) pointed out that language program administration as a profession, distinct from that of an ESL teacher, is beginning to emerge. It is worth acknowledging that those who lead ESL programs post-secondary contexts are highly competent professionals who have developed substantial leadership skills and business acumen through on-the-job experience. Those who hold these leadership roles today could play a part in training and coaching those who may follow in their footsteps in the future.

\section{Recommendations}

A primary recommendation emerging from this study is that TESOL graduate programs must include a leadership component to provide more training and support for those in the profession. Management skills have not typically been included in the types of degree programs taken by TESL professionals, such as an MA or MEd (Hussein, 1995; Reasor, 1986). Hussein (1995) suggested that TESOL and applied linguistics programs should either include administrative training or require students take such courses through a complementary department, such as educational administration.

Not only do current ESL program administrators, as a body of professionals with deep expertise and experience, have the opportunity to train the next generation of ESL program administrators, we must provide professional development opportunities for those currently serving in administrative roles (McGee et al., 2014). Hussein (1995) suggested that professional associations can facilitate further development those in administrative roles through workshops and presentations at their annual conferences.

Leaders rely on their own first-hand experience as well as on their interactions with professional peers with whom they work in similar contexts (McGee et al., 2014; Sergiovanni, 1991). By incorporating components of leadership and 
educational administration into graduate-level TESOL programs and complementing that with professional development for those who already serve in leadership roles, current TESOL professionals would cultivate the next generation of program directors who could lead programs with skills and confidence, while also having a network of peers with similar administrative training upon whom they could rely for consultation and advice.

In addition, there is a need for a candid dialogue about the value ESL programs bring to higher education not merely for their monetary contributions, but for the much-needed support and services they provide to international students. Institutions themselves carry substantial responsibility when it comes to elevating the profile and prestige of ESL programs on campus. Only when these programs receive considerable institutional support will they be legitimized as authentic contributors to the academic community. Acknowledging the emergence of language program administration as a profession distinct from that of teaching is a valuable first step in elevating and empowering ESL program directors, who serve the dual, if often competing, purpose of producing revenue for their institutions while simultaneously preparing English language learners for academic and professional success.

\section{References}

Eaton, S. E. (2009). Marketing of Revenue-generating ESL Programs at the University of Calgary: A qualitative study. (Doctor of Philosophy), University of Calgary, Calgary. Retrieved from http://www.eric.ed.gov/ERICWebPortal/contentdelivery/servlet/ERICServlet ?accno=ED508999

Eaton, S. E. (2013). The Administration of English as a Second Language (ESL) Programs in Higher Education: Striking the Balance Between Generating Revenue and Serving Students. In Y. Hébert \& A. A. Abdi (Eds.), Critical Perspectives on International Education (pp. 165-180). Rotterdam: Sense. doi: https://doi.org/10.1007/978-94-6091-906-0_10

Bista, K. (2011). How to create a learning-centered ESL program. English for Specific Purposes World, 31(10). Retrieved from http://www.espworld.info/Articles_31/Ring-centered_Program.pdf

Blackstone, A. (2017). Principles of sociological inquiry: Qualitative and quantitative methods, $\quad$ v. $1.0 . \quad$ Retrieved from http://catalog.flatworldknowledge.com/catalog/editions/blackstoneprinciples-of-sociological-inquiry-qualitative-and-quantitative-methods-1-0

Breshears, S. (2004). Professionalization and exclusion in ESL teaching [special issue]. TESL Canada Journal, 4, 23-39. https://doi.org/10.18806/tesl.v0i0.1038.

Carkin, S. (1997). Language program leadership as intercultural management. In M. A. Christison \& F. L. Stoller (Eds.), A handbook for language program administrators (pp. 49-60). Burlingame, CA: Alta Book Center Publishers.

Chapelle, C. A., \& Duff, P. A. (2003). Some guidelines for conducting quantitative and qualitative research in TESOL. TESOL Quarterly, 37(1), 157-178. https://doi.org/10.2307/3588471. Retrieved from https://www.tesol.org/readand-publish/journals/tesol-quarterly

Christison, M., \& Murray, D. E. (Eds.). (2009). Leadership in English language education: Theoretical foundations and practical skills for changing times. New York, NY: Taylor \& Francis. https:// doi.org/10.4324/9780203077009 
Coombe, C., McCloskey, M., Stephenson, L., \& Anderson, N. (Eds.). (2008). Leadership in English language teaching and learning. Ann Arbor, MI: University of Michigan Press. https://doi.org/10.1108/s2041-272x(2010)0000002020

Curtis, A. (2013). A gap in our field: Leadership in language education. MultiBriefs. Retrieved from http://exclusive.multibriefs.com/content/a-gap-in-our-fieldleadership-in-language-education

Eskey, D. E. (1997). The IEP as a nontraditional entity. In M. A. Christison \& F. L. Stoller (Eds.), A handbook for language program administrators (pp. 21-30). Burlingame, CA: Alta Book Center.

Fylan, F. (2005). Semi-structured interviewing. In J. Miles \& P. Gilbert (Eds.), A handbook of research methods for clinical and health psychology (pp. 65-77). Oxford, UK: Oxford University Press. https://doi.org/10.1093/med:psych/9780198527565.001.0001

Greenier, V. T., \& Whitehead, G. E. K. (2016). Towards a model of teacher leadership in ELT: Authentic leadership in classroom practice. RELC Journal, 47(1), 79-95. https://doi.org/10.1177/0033688216631203. Retrieved from http://journals.sagepub.com/home/rel

Harrell, M. C., \& Bradley, M. A. (2009). Training manual: Data collection methods: Semistructured interviews and focus groups. Retrieved from http:// www.mbamedicine.activemoodle.com/ mod/resource/view.php?id=486

Heifetz, R. A. (1994). Leadership without easy answers. Cambridge, MA: The Belknap Press of Harvard UP.

Heifetz, R. A. (2006). Educational leadership: Beyond a focus on instruction. The Phi Delta Kappan, 87(7), 512-513. Retrieved from http://journals.sagepub.com/home/pdk https://doi.org/10.1177/003172170608700709

Heifetz, R. A. (2010, Spring). Adaptive work. The Journal of the Kansas Leadership Center, 72-77. Retrieved from https://klcjournal.com/

Heifetz, R. A., Grashow, A., \& Linsky, M. (2009, July-August). Leadership in a (permanent) crisis. Harvard Business Review, 62-69. Retrieved from https://hbr.org/2009/07/leadership-in-a-permanent-crisis

Heifetz, R. A., \& Laurie, D. L. (1997). The work of leadership. Harvard Business Review, 124-134.

Heifetz, R. A., \& Linsky, M. (2004). When leadership spells danger. Educational Leadership, 61(7), 33. Retrieved from http://www.ascd.org/publications/educational-leadership.aspx

Hussein, A. A. (1995). Preparation for administration of English as a second language programs. Paper presented at the Annual Meeting of the Teachers of English as a Second Language (TESOL) Association, Long Beach, CA. Retrieved from https://ia601308.us.archive.org/23/items/ERIC_ED392258/ERIC_ED392258.p $\mathrm{df}$

Impey, G., \& Underhill, N. (1994). The ELT manager's handbook: Practical advice on managing a successful language school. Oxford, UK: Heineman English Language Teaching.

Jenks, F. L. (1997). The quest for academic legitimacy: Building for language program entry into institutional and community infrastructures. In M. A. Christison \& F. L. Stoller (Eds.), A handbook for language program administrators (pp. 107-122). Burlingame, CA: Alta Book Center.

Jenks, F. L., \& Kennell, P. (2012). The quest for academic legitimacy. In M. Christison \& F. L. Stoller (Eds.), Handbook for language program administrators (2nd. ed., pp. 177-196). Burlingame, CA: Alta Book Center.

Kaplan, R. B. (1997). An IEP is a many-splendored thing. In M. A. Christison \& F. L. Stoller (Eds.), A handbook for language program administrators (pp. 3-20). 
Burlingame, CA: Alta Book Center.

Luo, L., \& Wildemuth, B. M. (2009). Semistructured interviews. In B. M. Wildemuth (Ed.), Applications of social research methods to questions in information and library science (pp. 222-231). Westport, CT: Libraries Unlimited.

MacDonald, J. (2016) The margins as third space: EAP teacher professionalism in Canadian universities. TESL Canada Journal, 34(1), 106-116. https://doi.org/10.18806/tesl.v34i1.1258. Retrieved from http://teslcanadajournal.ca/tesl/index.php/tesl/article/view/1258

Matthies, B. F. (1984). The director's job skills in intensive English programs. The American Language Journal, 2(1), 5-16. Retrieved from http://files.eric.ed.gov/fulltext/ED248691.pdf

McGee, A., Haworth, P., \& MacIntyre, L. (2014). Leadership practices to support teaching and learning for English language learners. TESOL Quarterly, 49(1), 92114. https://doi.org/10.1002/tesq.162. Retrieved from https://www.tesol.org/read-and-publish/journals/tesol-quarterly

Merriam, S. B. (1998). Qualitative research and case study applications in education. San Francisco, CA: Jossey-Bass.

Merriam, S. B., \& Tisdell, E. J. (2016). Qualitative research: A guide to design and implementation (4th ed.). San Francisco, CA: Jossey-Bass.

Mickelson, C. (1997). Grants and projects (as if you don't have enough to do already). In M. A. Christison \& F. L. Stoller (Eds.), A handbook for language program administrators (pp. 275-294). Burlingame, CA: Alta Book Center.

Murdock, R. S. (1997). Outreach on and off campus. In M. A. Christison \& F. L. Stoller (Eds.), A handbook for language program administrators (pp. 161-174). Burlingame, CA: Alta Book Center.

Nolan, R. E. (2001). The power of theory in the administration of ESL programs. Adult Basic Education, 11(1), 3-17. Retrieved from https://www.learntechlib.org/j/ISSN-1052-231X

Norris, J. M. (2016). Language program evaluation. The Modern Language Journal, 100(S1), 169-189. https://doi.org/10.1111/modl.12307. Retrieved from http://onlinelibrary.wiley.com/journal/10.1111/(ISSN)1540-4781

Panferov, S. K. (2012). Transitioning from teacher to language program administrator. In M. Christison \& F. L. Stoller (Eds.), Handbook for language program administrators (2nd ed., pp. 3-18). Burlingame, CA: Alta Book Center.

Pennington, M. C. (1991). Work satisfaction and the ESL profession. Language, Culture, and Curriculum, 4(1), 59-86. https://doi.org/10.1080/07908319109525094. Retrieved from http://www.tandfonline.com/loi/rlcc20

Pennington, M. C., \& Hoekje, B. J. (2010). Language program as ecology: A perspective for leadership. RELC Journal, 41(3), 213-228. https://doi.org/10.1177/0033688210380556. Retrieved from http://journals.sagepub.com/home/rel

Pennington, M. C., \& Hoekje, B. J. (2014). Framing English language teaching. System, 46, 163-175. https://doi.org/10.1016/j.system.2014.08.005. Retrieved from http://www.sciencedirect.com/science/article/pii/S0346251X14001316

Pennington, M. C., \& Xiao, Y. (1990). Defining the job of the ESL program director: Results of a national survey. University Hawai'i Working Papers in ESL, 9(2), 1-30. Retrieved from http://hdl.handle.net/10125/38623

Rawley, L. A. (1997). The language program administrator and policy formation at institutions of higher learning. In M. A. Christison \& F. L. Stoller (Eds.), A handbook for language program administrators (pp. 91-104). Burlingame, CA: Alta Book Center.

Reasor, A. W. (1986). Dominant administrative styles of ESL administrators. TESOL Quarterly, 20(2), 338-343. https://doi.org/10.2307/3586550. Retrieved from 
https://www.tesol.org/read-and-publish/journals/tesol-quarterly

Rowe, J. A. (2012). Decision maker and negotiator. In M. Christison \& F. L. Stoller (Eds.), Handbook for language program administrators (2nd. ed., pp. 99-116). Burlingame, CA: Alta Book Center.

Rowe-Henry, A. (1997). The decision maker and negotiator. In M. A. Christison \& F. L. Stoller (Eds.), A handbook for language program administrators (pp. 77-90). Burlingame, CA: Alta Book Center.

Saldaña, J. (2009). The coding manual for qualitative researchers. Thousand Oaks, CA: Sage.

Saunders, M. N. K. (2012). Choosing research participants. In G. Symon \& C. Cassell (Eds.), Qualitative organizational research: core methods and current challenges (pp. 35-54). London, UK: SAGE.

Sergiovanni, T. J. (1991). Constructing and changing theories of practice: The key to preparing school administrators. The Urban Review, 23(1), 39-49. https://doi.org/10.1007 /BF01120237. Retrieved from https://link.springer.com/journal/11256

Soppelsa, E. F. (1997). Empowerment of faculty. In M. A. Christison \& F. L. Stoller (Eds.), A handbook for language program administrators (pp. 123-142). Burlingame, CA: Alta Book Center.

Staczek, J. J. (1997). The language program budget: Financial planning and management of resources. In M. A. Christison \& F. L. Stoller (Eds.), A handbook for language program administrators (pp. 219-234). Burlingame, CA: Alta Book Center.

Staczek, J. J., \& Carkin, S. J. (1984). Intensive English program fit in traditional academic settings: Practices and promise. Paper presented at the Eighteenth Annual Convention of Teachers of English to Speakers of Other Languages (TESOL), Houston, TX. Retrieved from http:// files.eric.ed.gov/fulltext/ED274166.pdf

Stoller, F. L. (1997). The catalyst for change and innovation. In M. A. Christison \& F. L. Stoller (Eds.), A handbook for language program administrators (pp. 33-48). Burlingame, CA: Alta Book Center Publishers.

Stoller, F. L., \& Christison, M. (1994). Challenges for IEP administrators: Liaison with senior-level administrators and faculty development. TESOL Journal, 3(3), 16-20. Retrieved from https://www.tesol.org/read-and-publish/journals/tesoljournal

Szasz, P. (2009/2010). State of the profession: Intensive English programs. CATESOL Journal, 21(1), 194-201. Retrieved from http:/ / files.eric.ed.gov/fulltext/EJ1112266.pdf 